\title{
Shelf Life Study of Ready-to-Eat Buffalo Meat Curry
}

\author{
Mohammad Ali Khan ${ }^{1}$, Mahjabeen Siddiqui ${ }^{1}$ Krishna Kumar Patel ${ }^{1 *}$ and P. Chaudhary ${ }^{2}$ \\ ${ }^{1}$ Department of Post-Harvest Engineering and Technology, Aligarh Muslim University, Aligarh 202002 (India) \\ ${ }^{2}$ Department of Microbiology, School of Life Science, Khandari campus, DR. B. R. Ambedkar University, \\ *E-mail: k_krishna_374@yahoo.co.in
}

\begin{abstract}
As exports of value added meat products are insignificant. Continue growing of poultry, buffalo, sheep and goat based meat processing industry has big opportunity. The growing number of fast food outlets in the domestic market also has had a significant impact on the meat processing industry. But, due to many preparatory steps and longer preparation time of traditional Indian meat based foods, the quality maintenance of meat based products is cause of concern. To avoid the burden of such processing steps and simultaneously to meet the demand, the ready-to-eat meat products have been found better option. Indian and overseas market of ready-to-eat meat products is, therefore, continuously on the growing stage. The present study, thus, focused on the shelf life enhancement of the ready-to-eat buffalo meat curry at ambient temperature and refrigerated storage condition. Considering the above goal, ready-to-eat buffalo meat curry were packed using heat sealing machine in retort pouches and stored at ambient temperature $\left(37 \pm 1^{\circ} \mathrm{C}\right)$. Further, the quality of the products were evaluated by studying the microbiological characteristics including total plate count (TPC), yeast and mold (Y\&M) count, Coliform count, Staphyloccous Salmonella, Shigella and lypolytic count and proteolytic count. The result of this study explored that the treated products were acceptable up-to 5 days of storage.
\end{abstract}

Keywords: Ready-to eat, meat, curry, microbiological, shelf life, ambient temperature.

\section{Introduction}

India's total meat production in 2010-11 was estimated at 4.8 million tonne as compared to 4.6 million tonne in 2009-10 indicating growth rate of 5.7\% [1]. However, according to Sarathy and Gopal [2], the market of Ready-To-Eat (RTE) foods in India is currently of about Rs. 130Cr. It was expected to further expand to Rs $2900 \mathrm{Cr}$ by 2015 because of its high demand and nutritional value. Meat is widely consumed as a source of protein not only in India but also in many other developing countries like as Bangladesh, China, Pakistan, etc. Meat is also rich in amino acid composition complements than that of cereals and other vegetable. It is a good source of iron and zinc and several B vitamins, and liver is a very rich source of vitamin A. Since meat is highly susceptible to spoilage, it is either eaten cooked or processed into other forms to avoid associated spoilage. India's per capita buffalo meat consumption is estimated at approximately two kilograms per year.

Meat is defined as the edible part of the skeletal muscle of an animal that was healthy at the time of slaughter [3]. The relative proportions of major components (water, protein, lipid, carbohydrate) and with some minor components (enzymes, flavour compounds, pigments and vitamins, etc) give meat its particular structure, texture, flavour, colour and nutritive value [4]. Because of such high nutritive value and its unique biological and chemical nature, meat undergoes progressive deterioration from the time of slaughter until consumption because of its nutritious, protein-rich nature. Meat spoilage during distribution can be considered as an ecological phenomenon that encompasses the changes of the available substrata (e.g., low molecular compounds), during the prevailing of a particular microbial association, the so-called specific spoilage organisms (SSO). In fact, spoilage of meat depends on an even smaller fraction of SSO, called ephemeral spoilage organisms (ESO). These ESO are the consequence of factors that dynamically persist or imposed during processing, transportation and storage in the market [5]. Meat and meat product is highly perishable and has a short shelf-life unless preservation methods are used. Meanwhile spoilage is a subjective judgment by the consumer, which may be influenced by cultural and economic considerations and background as well as by the sensory activity of the individual and the intensity of the change. There are other various factors such as ingredients; thermal effects, 
emulsification, and acidification that effect quality attributes of food products. Shelf life and maintenance of the meat quality are influenced by a number of interrelated factors including holding temperature [6]. Spoilage by microbial growth is the most important factor in relation to the keeping quality of meat [4]. Several studies have reported that the daily meats are of high risk due to the potential for contamination with Listeria monocytogenes $[7,8]$ and the L. monocytogenes were also identified that it has the highest risk for meats [9]. The absence of a listericidal step such as cooking, extended shelf life and /or contamination during handling subsequent to a listericidal step (ie.during slicing) and the ability of many of these products to support the growth of L. monocytogenes during storage, even under refrigeration were generally responsible for such type of high risk.[10] found that changes in $\mathrm{pH}$, TBARS, tyrosine value and microbial counts influenced the quality of hurdle treated pork sausages stored at ambient temperature.

Furthermore, it was noticed of injection of brine containing salt and nitrite in cured meat followed by soaking or massaging and then cooking at $65^{\circ} \mathrm{C}$ for 10 minutes ensures a $6 \log$ reduction in $\mathrm{L}$. monocytogenes present on the meat. However, subsequent handling may re-introduce this organism [11] and the handling activities that may contribute considerably to the contamination of RTE meat products with pathogenic bacteria $[12,13]$. However, shelf life of the products packed in vacuum or modified atmosphere packaging (MAP) can be extended to several weeks by inhibiting the growth of spoilage organisms by refrigeration. Refrigeration can control pathogenic organisms such as Salmonella but the growth of psychrotrophic (cold tolerant) organisms such as L. monocytogenes will not be inhibited by this technique. In another study, Beume et al. [14] found that when a sample of ham was inoculated with $10 \mathrm{cfu} / \mathrm{g}$ of L. monocytogenes, the organism grew to levels of $108 \mathrm{cfu} / \mathrm{g}$ within 35 days, with the presence of CO2 in the packaging. Similarly, fermented sausages are considered high risk due to primarily contamination and survival of pathogenic Escherichia coli, particularly if the fermentation process is not adequately controlled [15]. In addition to above, several microbes such as L. monocytogenes, Clostridium perfringens, E. coli O157 and O111, Staphylococcus and Salmonella [16] have been found responsible for contamination of meat and meat product.

By using refrigeration noticeable level of risk of deterioration in meat and meat product can be reduced. But, in developing countries, refrigerators are not commonly available in every household. Simultaneously, frequent interruption in power supply caused problem in proper refrigeration. These situations, therefore, restrict the people from processing the buffalo meat curry and thus they eat it fresh. Some people store the surplus, reheat and consume on the next day or within $24 \mathrm{~h}$ of preparation. Scientific processing accompanied by good manufacturing practices and suitable packaging could improve the shelf life of the buffalo meat curry without refrigeration. Considering the above facts the main goal of this study was to develop and treat the ready to eat buffalo meat curry with different preservatives and study the effect of preservatives on shelf life at ambient temperature $\left(32 \pm 2^{\circ} \mathrm{C}\right)$.

\section{Material and Methods}

Fresh buffalo meat, spices and condiments, salt, oils, preservatives and packaging materials (Low density poly ethylene) were used in this research. All these raw materials were procured from Jamalpur, the local market of Aligarh, and brought to the laboratory of Department of Post Harvest Engineering and Technology, AMU, Aligarh for further processing and product development. The procurement of buffalo meat was done very carefully from meat shop within $4 \mathrm{hrs}$ of slaughtering. The buffalo meat collected from the buffalos was slaughtered from traditional halal method at slaughterhouse of municipal corporation, Aligarh where buffalos were kept in lairage for a period of 18-20 hours before slaughtering. Meat from round portion (biceps femoris muscle) of 2 to 5 years aged female carcasses were preferred. Buffalo fat from brisket and back and along with other meat ingredients. After raw material procurement, they were cleaned, sieved, washed and dried in tray drier oven at $60^{\circ} \mathrm{C}$ temperature and then grind to obtained fine powder. Table 1, represents the list of various ingredients and their quantity used in development of buffalo meat ready-to-eat curry. All ingredients were procured in package made by reputed company such as Goldi, DMD, etc. and sold by local retailers.

\subsection{Product Optimization}


The optimization of samples was based on sensory evaluation. Various samples (buffalo meat ready-toeat curry) were prepared traditionally and requested to the 12 expert panelists for sensory evaluation to suggest the best sample. On the basis of suggestion of expert the selection of final compositions was decided. The ingredients, thus, finalized mentioned in Table 1 were ground using grinder. The development procedure of buffalo meat ready-to-eat curry is given in the flow diagram (Fig. 1). The developed sample was treated with three preservatives: calcium chloride, sodium diacetate and calcium chloride-sodium diacetate mix and packed in laminates pouches of Polyster-Nylon-Aluminiumpolypropylene and stored at ambient conditions. The sample taken untreated was considered as control sample.

Table1. The ingredients used in buffalo meat ready-to-eat curry.

\begin{tabular}{lllc}
\hline S.No & Ingredient & Genric name & Quantity $(\mathrm{g} / \mathbf{k g})$ \\
\hline 1 & Aniseed & Soanf & 2.0 \\
2 & Black pepper (DMD) & Kali mirch & 1.0 \\
3 & Bayleaf & Tejpatha & 1.0 \\
4 & Capsicum (DMD) & Mirch powder & 8.0 \\
5 & Cumin seed & Zeera & 2.0 \\
6 & Coriander powder (Goldi) & Dhania & 50 \\
7 & Cinnamon & Dal chini & 1.0 \\
8 & Cloves & Laung & 1.0 \\
9 & Cardamom & choti elaichi & 1.0 \\
10 & Cardamom & Badi elaichi & 1.0 \\
11 & Garlic & Lahsun & 20 \\
12 & Ginger & Adrak & 20 \\
13 & Nutmeg & Jaiphal & 1.0 \\
14 & Mace & Javithri & 1.0 \\
15 & Salt (Tata) & Namak & 15 \\
16 & Turmeric (DMD) & Haldi & 15 \\
\hline
\end{tabular}

\subsection{Shelf Life Studies on Basis of Microbiological Analysis}

Microbiological studies of products determined as per the methods described by Andrews et al. [17]. $10 \mathrm{~g}$ meat sample was homogenized in $90 \mathrm{ml}$ of normal saline solution (NSS) and serial dilution up to $10^{-6}$ dilution and $0.1 \mathrm{ml}$ sample of each dilution was spread on selective media plates under aseptic conditions. Nutrient agar and PDA media were used to determine total plate count, yeast and mould count respectively. After that inoculated plates were incubated at $37^{\circ} \mathrm{C}$ for 24 to $48 \mathrm{~h}$. The bacterial and fungal counts were determined and presented as described by APHA [18].

$$
T P C(c f u / g m)=\frac{\text { No. of colonies }}{\text { Amountusedforinoculation } X \text { Dilutionfactor }}
$$

To study the bacterial count, yeast mold count, fungi, lipase and protease enzyme in ready to eat meat curry various media were prepared during microbial analysis. The compositions of these media are given below in Tables $2 \mathrm{a}, 2 \mathrm{~b}$ and $2 \mathrm{c}$ : 


\section{Frying- $\mathrm{I}^{\text {st }}$}

(Buffalo meat using sufficient quantity of oil in a pressure cooker for $10 \mathrm{~min}$ and after that take it out)

$$
\text { Frying-II nd }
$$

(Ginger and garlic in same left oil)

Addition of spices and condiments mix and cooking till oil separates then add required quantity of water

$$
\downarrow
$$

Addition of fried buffalo meat pieces and all the ingredients and mixed well

$$
\downarrow
$$

Cooking in pressure cooker on a mild heat for 25 min meat or till tenderness

The buffalo meat ready-to-eat curry was cooled to the room temperature $\left(37 \pm 4^{0} \mathrm{C}\right)$ and poured into the sterilizable pouches.

$$
\begin{gathered}
\text { Atmospheric packaging in laminated pouches } \\
\text { (Polyster-Nylon-Aluminium-polypropylene } \\
\downarrow \\
\text { Sterilization of meat ready-to-eat curry } \\
\text { (at } 121^{\circ} \mathrm{C} \text { for } 30 \text { min in an autoclave) } \\
\downarrow \\
\text { Cool to room temperature (37 } 14^{\circ} \mathrm{C} \text { ) } \\
\downarrow \\
\text { Storage at } 37 \pm 4^{\circ} \mathrm{C} \text { (Incubator) }
\end{gathered}
$$

Figure 1. Flow diagram of buffalo meat ready-to-eat curry.

Table 2a. Nutrient agar composition and its quantity description

\begin{tabular}{ll}
\hline Nutrient agar composition & Quantity $(\mathrm{g} / \mathrm{L})$ \\
\hline Beef extract & 3.0 \\
Peptone & 5.0 \\
Sodium chloride & 5.0 \\
Agar & 15.0 \\
pH & $6.8 \pm 0.2$ \\
Potato dextrose agar & \\
Potato infusion & 200.0 \\
Dextrose & 20.0 \\
Agar & 20.0 \\
pH & $5.6 \pm 0.2$ \\
$*$ For yeast and mold, streptomycin $(40 \mu \mathrm{g} / \mathrm{ml})$ was added \\
Normal saline solution (NSS) \\
Sodium chloride & $8.6 \mathrm{~g}$ \\
\hline
\end{tabular}

Table 2b. Baired-parker medium (gram per liter) composition

\begin{tabular}{lc}
\hline Baired-parker medium (gram per liter) & composition \\
\hline Typtone & 10.0 \\
Beef extract & 5.0 \\
Yeast extract & 1.0 \\
Sodium pyruvate & 10.0 \\
\hline
\end{tabular}




\begin{tabular}{ll}
\hline Glycine & 12.0 \\
Lithium chloride & 5.0 \\
Agar & 20 \\
pH & $7.0 \pm 0.2$ \\
*Egg yolk tellurite enrichment & $50.0 \mathrm{ml}$ \\
SS Agar (Salmonella \& Shigella ) composition \\
Peptic digest of animal tissue & 5.0 \\
Beef extract & 5.0 \\
Lactose & 10.0 \\
Bile salt mixture & 8.50 \\
Sodium citrate & 10.0 \\
Sodium thiosulphate & 8.50 \\
Ferric citrate & 1.0 \\
Brilliant green & 0.00033 \\
Neutral red & 0.025 \\
Agar & 15.0 \\
pH & $7.00 \pm .2$ \\
Note: No need of autoclave or overheat & \\
\hline
\end{tabular}

Table 2c. Hekton Enteric Agar composition

\begin{tabular}{lc}
\hline Hekton Enteric Agar composition & (gram per liter) \\
\hline Protease peptone & 12.00 \\
Yeast extract & 3.00 \\
Lactose & 12.00 \\
Salicin & 2.00 \\
Bile salt mixture & 9.00 \\
Sodium Chloride & 5.00 \\
Sodium thiosulphate & 5.00 \\
Ferric ammonium citrate & 1.50 \\
Acid fuchsin & 0.10 \\
Bromo thymal blue & 0.065 \\
Agar & 15.0 \\
Ph & $7.2 \pm 0.2$ \\
Milk agar composition & \\
Skim milk agar & 100.0 \\
Peptone & 5.0 \\
Agar & 15.0 \\
Tributyrin agar composition & \\
Peptone & 5.0 \\
Yeast extract & 3.0 \\
Tributyrin & $10.0 \mathrm{ml}$ \\
Agar & 15.0 \\
PH & $5.6 \pm 0.20$ \\
Rose bengal chloramphenicol agar composition \\
Mycological peptone & 5.00 \\
Pextrase & 10.00 \\
Monopotassium phosphate & 1.00 \\
Magnesium sulphate & 0.50 \\
Rose Bangal & 0.05 \\
Chlroamphnicol & 1.10 \\
Agar & 15.50 \\
PH & $7.2 \pm 0.2$ \\
\hline
\end{tabular}




\section{Results and Discussion}

This research revealed the effect of calcium chloride, sodium diacetate and calcium chloride-sodium diacetate mix treatments on ready-to-eat buffalo meat curry stored at ambient conditions. On the basis of microbiological characteristics of products, characteristics changes during preservation at different storage temperature have been discussed with a view to access the shelf life of the product. The microbial quality of ready-to-eat buffalo meat curry was evaluated periodically at every $2^{\text {nd }}$ days of storage interval at ambient temperature $\left(37^{\circ} \mathrm{C}\right)$. Certain important microbial of food contamination viz. total plate count (TPC), yeast and mold (Y\&M), Salmonella, Shigella count, Staphylocoous count and Lypolytic count and Proteolytic count were recorded. The results have been displayed in Table 3 to Table 8 .

The mean values for microbial profile of ready-to-eat buffalo meat curry during ambient storage are presented in Table 3. The total plate counts (TPC) increased rapidly after 3 days of storage with increasing storage period in control and sodium diacetate treated sample. In control sample the total plate count on day one was nil but at day 2 the count was found and which was further found to be increased with increasing storage period. Calcium chloride treated sample showed no count up to 3 days but after 4 days the counts were found to be increased with increasing storage period. Initially TPC count was not detected due to sterilization at $121^{\circ} \mathrm{C}$ for $30 \mathrm{~min}$ might be due to the destruction of the microbes at such high temperature and pressure. Even the mild heat treatment of $60^{\circ} \mathrm{C}$ has also been reported to lower the microbial load [19]. However, the results showed that the TPC values of control RTE sample increased with time during storage at ambient condition while TPC of preservatives treated sample were not detected on day 1. But after 3 days the counts were detected in sodium diacetate and calcium chloride treated RTE samples which was found to be further increased with increasing storage period. In contrast, the treatment of sodium diacetate and calcium chloride both in combination showed better results among all treatments for increasing the shelf-life of the product under atmospheric packaging and found most suitable.

Table 3. Total Plate Count of untreated and treated ready-to-eat buffalo meat curry stored at ambient storage (37 $\left.\pm 1^{\circ} \mathrm{C}\right)$.

\begin{tabular}{lccccc}
\hline Sample code & \multicolumn{5}{c}{ Total Plate Count in (x10 CFU/g) } \\
\cline { 2 - 6 } & $\mathbf{5}$ & $\mathbf{2}$ & $\mathbf{4}$ & $\mathbf{6}$ & $\mathbf{8}$ \\
& $\mathbf{0}$ & Storage Period (No of Days) & & \\
Control & ND & $0.47 \pm 0.03$ & $1.82 \pm 0.11$ & $3.25 \pm 0.29$ & $6.45 \pm 0.25$ \\
SD & ND & ND & $0.25 \pm 0.21$ & $1.67 \pm 0.53$ & $3.24 \pm 0.15$ \\
CL & ND & ND & ND & $0.86 \pm 0.45$ & $3.11 \pm 0.20$ \\
SDCL & ND & ND & $0.31 \pm 0.12$ & $1.45 \pm 0.53$ & $2.02 \pm 0.67$ \\
\hline
\end{tabular}

Note:- SD: sodium diacetate, CL: calcium chloride and SDCL: sodium diacetate and calcium chloride treated in combination

Table 4 displays results of yeast and mold counts of four samples of ready-to-eat buffalo meat curry evaluated in the fresh condition and during ambient storage. On day 1, all samples showed absence of yeast and mould but the count appeared and was found to increase with increasing storage period. However, the control/untreated RTE sample on day 2 count of yeast and mold, as determined, was 0.11 $\mathrm{x} 10^{3} \mathrm{CFU} / \mathrm{g}$ which was found to be increased to $7.37 \times 10^{3} \mathrm{CFU} / \mathrm{g}$ on $8^{\text {th }}$ day of storage (Table 4$)$. In general, Yeast and mould count profiles of ready-to-eat buffalo meat curry of control sample were found on increasing trend during storage. Further, the YMC $(\mathrm{cfu} / \mathrm{g})$ in sodium diacetate treated ready-to-eat buffalo meat curry indicated an increasing trend during storage at ambient temperature at the $2^{\text {nd }}$ day of storage and also beyond the $2^{\text {nd }}$ day and till the $8^{\text {th }}$ day of storage. Similarly, the calcium chloride treated ready-to-eat buffalo meat curry showed no count up to the $4^{\text {rth }}$ day of storage. However, after that $\left(4^{\text {rth }}\right.$ day), the increasing trend was again observed and the counts were found $0.14 \mathrm{cfu} / \mathrm{g}$ at day 6 .

In addition, sodium diacetate and calcium chloride treated samples in combination showed no fungal count even up to $6^{\text {th }}$ of storage. The fungal counts found in developed samples were isolated and 
identified on the basis of morphology. Fig. 2 to 3 shows three types of fungi grown on rose Bengal agar media inoculated with ready to eat meat curry developed during the research work in laboratory. The trend of yeast and mould count in ready-to-eat bufallo meat curry treated with Sodium diacetate, calcium chloride, Sodium diacetate \& calcium chloride in combination and in control sample was found as control $>$ Sodium diacetate $>$ calcium chloride $>$ Sodium diacetate and calcium chloridein combination. Thus, the least count of YM was reported in ready-to-eat meat curry sample which were treated with Sodium diacetate \& calcium chloride in combination. On the basis of microscope identification of fungi, it was observed that the Rhizopus and Aspergillus, the main contaminants were isolated from curry stored at ambient storage $\left(37 \pm 1^{\circ} \mathrm{C}\right)$.

Table 4. Yeast and Mold Count of untreated and treated ready-to-eat buffalo meat curry stored at ambient storage $\left(37 \pm 1^{\circ} \mathrm{C}\right)$.

\begin{tabular}{lccccc}
\hline Sample code & \multicolumn{5}{c}{ Yeast and Mold Count in (x10 $\left.\mathbf{3}^{\mathbf{C}} \mathrm{CFU} / \mathrm{g}\right)$} \\
\cline { 2 - 6 } & $\mathbf{0}$ & $\mathbf{2}$ & $\mathbf{4}$ & $\mathbf{6}$ & $\mathbf{8}$ \\
Control & $\mathrm{ND}$ & $0.11 \pm 0.21$ & $0.33 \pm 0.27$ & $3.42 \pm 0.53$ & $7.37 \pm 0.02$ \\
SD & $\mathrm{ND}$ & $0.21 \pm 0.45$ & $0.34 \pm 0.15$ & $0.78 \pm 0.43$ & $0.82 \pm 0.12$ \\
CL & $\mathrm{ND}$ & ND & ND & $0.14 \pm 0.11$ & $0.45 \pm 0.31$ \\
SDCL & ND & ND & ND & ND & $0.08 \pm 0.23$ \\
\hline
\end{tabular}

Note:- SD: sodium diacetate...., CL: calcium chloride.... and SDCL: sodium diacetate and calcium chloride treated in combination ....

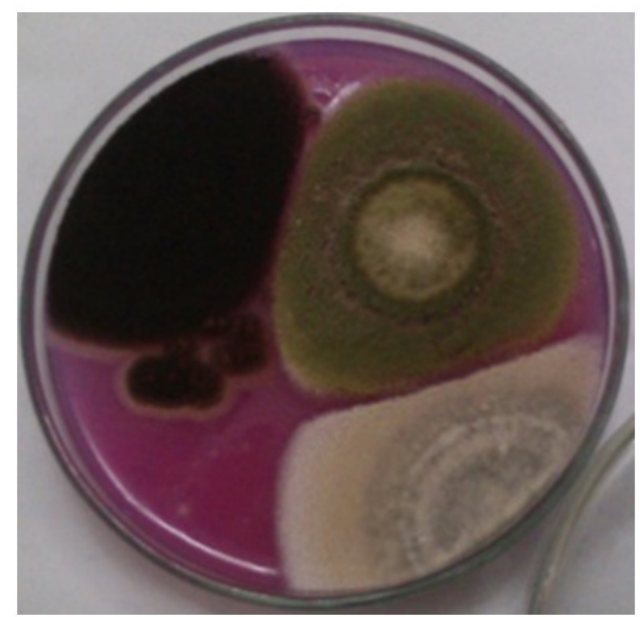

Figure 2. Fungal colonies on Rose Bengal Agar medium
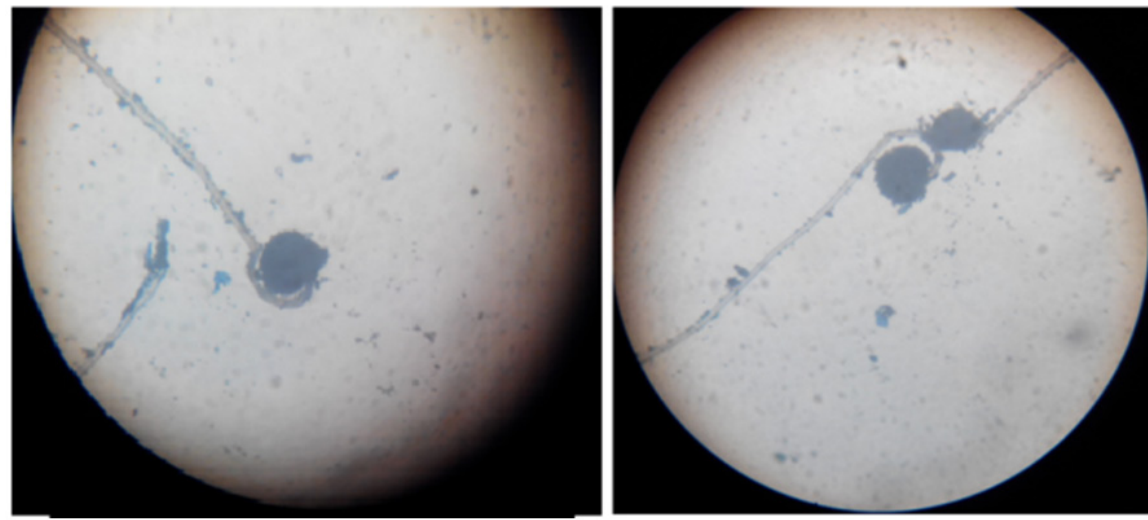

Figure 3. Rhizopus isolated from ready to eat buffalo meat curry 
Coliform count $(\mathrm{cfu} / \mathrm{g})$ was only obtained in control sample at $7^{\text {th }}$ day of storage (Table 5 ). In the samples treated with sodium diacetate, calcium chloride and also in combination of both, this organism was not detected until the $8^{\text {th }}$ day of storage. Similarly, in control (untreated) ready-to-eat buffalo meat curry, the Staphyloccous count (cfu/g) was not detected initially but as storage further advanced the population of Staphyloccous appeared on the $6^{\text {th }}$ and $8^{\text {th }}$ day. The population of organism was increased as the storage period prolonged. In contrast, it was noticed that the samples treated with either sodium diacetate or calcium chloride individually or in combination of both had the antimicrobial effects against Staphyloccous counts and Staphyloccous count was not detected in ready-to-eat buffalo meat curry during whole periods of storage.

Table 5. Coliform count of untreated and treated ready-to-eat buffalo meat curry stored at ambient storage (37 $\left.\pm 1^{\circ} \mathrm{C}\right)$.

\begin{tabular}{lccccc}
\hline Sample code & \multicolumn{5}{c}{ Coliform count in (x10 $\left.\mathbf{3}^{\mathbf{C}} \mathrm{CU} / \mathrm{g}\right)$} \\
\cline { 2 - 6 } & \multicolumn{5}{c}{ Storage Period (No of Days) } \\
\hline \multirow{3}{*}{ Control } & $\mathbf{0}$ & $\mathbf{2}$ & $\mathbf{4}$ & $\mathbf{6}$ & $\mathbf{8}$ \\
SD & ND & ND & ND & $0.15 \pm 0.27$ & $1.81 \pm 0.56$ \\
CL & ND & ND & ND & ND & ND \\
SDCL & ND & ND & ND & ND & ND \\
\hline
\end{tabular}

Note:- SD: sodium diacetate, CL: calcium chloride and SDCL: sodium diacetate and calcium chloride treated in combination

Table 6. Staphyloccous count of untreated and treated ready-to-eat buffalo meat curry stored at ambient storage $\left(37 \pm 1^{\circ} \mathrm{C}\right)$.

\begin{tabular}{lccccc}
\hline Sample code & \multicolumn{5}{c}{ Staphyloccous count in $\left(\mathrm{x} 10^{3} \mathrm{CFU} / \mathrm{g}\right)$} \\
\cline { 2 - 6 } & $\mathbf{0}$ & $\mathbf{2}$ & $\mathbf{4}$ & $\mathbf{6}$ & $\mathbf{8}$ \\
Control & $\mathrm{ND}$ & $0.11 \pm 0.32$ & $0.65 \pm 0.16$ & $1.43 \pm 0.34$ & $1.82 \pm 0.29$ \\
SD & ND & ND & ND & ND & ND \\
CL & ND & ND & ND & ND & ND \\
SDCL & ND & ND & ND & ND & ND \\
\hline
\end{tabular}

Note:- SD: sodium diacetate, CL: calcium chloride and SDCL: sodium diacetate and calcium chloride treated in combination

Further, Salmonella shigella was noticed in control ready-to-eat buffalo meat curry on day 4 . Salmonella shigella found in Sodium diacetate treated ready-to-eat buffalo meat curry during $6^{\text {th }}$ days storage study. On the other hand calcium chloride individually or in combination with Sodium diacetate when used for treatment of ready-to-eat buffalo meat curry during $8^{\text {th }}$ days storage, the Salmonella shigella were not found. Proteolytic and Lipolytic enzymatic activities of microorganisms are the most important cause for food spoilage and a limited food's shelf life. Proteolytic counts (Table 7) in control sample were found in increasing trend from the day 2 of storage. However, in sodium dicetate and calcium chloride treated ready-to-eat buffalo meat curry samples, the Proteolytic enzymatic activities was noticed on day 4 and 6, respectively (Table 7). The rate of Proteolytic activity was slightly higher in buffalo meat isolates than in cattle meat which is an agreement to the findings by Tawakkol and Khafaga [20].

Furthermore, the Table 8 shows that the Lipolytic count was found in control and sodium diacetate treated ready-to-eat buffalo meat curry on day 4 and day 6 , respectively. Calcium chloride and sodium diacetate and calcium chloride in combination treated ready-to-eat buffalo meat curry showed no Lypolytic activity. 
Table 7. Proteolytic count of untreated and treated ready-to-eat buffalo meat curry stored at ambient storage (37 $\left.\pm 1^{\circ} \mathrm{C}\right)$.

\begin{tabular}{lccccc}
\hline & \multicolumn{5}{c}{ Proteolytic count in (x10 CFU/g) } \\
\cline { 2 - 6 } Sample code & \multicolumn{5}{c}{ Storage Period (No of Days) } \\
\hline & $\mathbf{0}$ & $\mathbf{2}$ & $\mathbf{4}$ & $\mathbf{6}$ & $\mathbf{8}$ \\
Control & ND & $0.05 \pm 0.42$ & $0.18 \pm 0.23$ & $0.47 \pm 0.16$ & $0.73 \pm 0.12$ \\
SD & ND & ND & $0.08 \pm 0.32$ & $0.34 \pm 0.21$ & $0.34 \pm 0.21$ \\
CL & ND & ND & ND & $0.12 \pm 0.17$ & $0.27 \pm 0.21$ \\
SDCL & ND & ND & ND & ND & ND \\
\hline
\end{tabular}

Note:- Note:- SD: sodium diacetate, CL: calcium chloride and SDCL: sodium diacetate and calcium chloride treated in combination

Table 8. Lipolytic count of untreated and treated ready-to-eat buffalo meat curry stored at ambient storage (37 $\left.\pm 1^{\circ} \mathrm{C}\right)$.

\begin{tabular}{|c|c|c|c|c|c|}
\hline \multirow[t]{3}{*}{ Sample code } & \multicolumn{5}{|c|}{ Lipolytic count in $\left(\times 10^{3} \mathrm{CFU} / \mathrm{g}\right)$} \\
\hline & \multicolumn{5}{|c|}{ Storage Period (No of Days) } \\
\hline & 0 & 2 & 4 & 6 & 8 \\
\hline Control & ND & ND & $0.16 \pm 0.12$ & $0.37 \pm 0.24$ & $0.78 \pm 0.85$ \\
\hline SD & ND & ND & ND & $0.06 \pm 0.32$ & $0.23 \pm 0.11$ \\
\hline CL & ND & ND & ND & ND & ND \\
\hline SDCL & ND & ND & ND & ND & ND \\
\hline
\end{tabular}

Note:- SD: sodium diacetate, CL: calcium chloride and SDCL: sodium diacetate and calcium chloride treated in combination

The microbiological quality in terms of total plate count (TPC), yeast and mold (Y\&M), Coliform count, Staphyloccous Salmonella, Shigella count, Staphylocoous count and lypolytic count and proteolytic count, therefore, showed that all the samples are safe for up to 5 days storage. However, storage after the $5^{\text {th }}$ day at ambient condition affected the sensory properties.

\section{Conclusion}

This study was conducted to stabilize ready-to-eat buffalo meat curry at ambient and refrigerated storage. The compositions were selected after several preliminary trails of sensory analysis. This study showed that the microbiological quality in terms of total plate count (TPC), yeast and mold (Y\&M), Coliform count, Staphyloccous Salmonella, Shigella count, Staphylocoous count and lypolytic count and proteolytic count remained acceptable in all the samples up to 5 days of storage. The ready-to-eat buffalo meat curry developed using moist heat sterilization in the range of $121^{\circ} \mathrm{C}$ for $15 \mathrm{~min}$ had proved that laminates pouches of Polyster-Nylon-Aluminium-polypropylene better barrier of microbes up to 5 days of storage at $37^{\circ} \mathrm{C}$. Later storage at ambient condition affected the sensory properties. As, meat is good source of nutrient and the higher oxidation concentration promotes the bacterial flora deteriorate the product. The occurrence of microbial count such a high level indicates to improve the material or method of packaging. For the longer shelf life of this product at ambient temperature needs some consideration. The modified atmosphere packaging system could work to achieve the better shelf life at ambient temperature.

Acknowledgement. This research is part of work which was carried out under All India Coordinated Research project on Post Harvest Technology at Aligarh Muslim University Aligarh, which is sponsored by Indian Council of Agricultural Research through.

\section{References}


1. G.O.I. Annual Report, Department of Animal Husbandry, Dairing \& Fisheries. Ministry of Agriculture Government of India, New Delhi, (2011-2012).

2. T. Sarathy and S. Gopal. Managing the Diffusion of innovation in Ready-To-Eat Food Products in India. International Conference on E-business, Management and Economics IPEDR, Vol.25, IACSIT Press, Singapore, 2011.

3. C.F.D.A.R. Canadian Food and Drugs Act and Regulations. With amendments to May 31990 Section 14 Paragraph B.14.002[Sp] 64 Ottawa: The Queen's Printer, 1990.

4. A. D. Lambert, J. P Smith and K. L. Dodds. Shelf life extension and microbiological safety of fresh meat - A review. Food Microbiology, 8: 267-297, 1991.

5. G-JF Nychas, PN Skandamis, CC Tassou and KP Koutsoumanis Meat spoilage during distribution. Meat Science, 78: 77-89, 2008.

6. A. Olaoye and A. A. Onilude Investigation on the potential use of biological agents in the extension of fresh beef in Nigeria. World Journal of Microbiology and Biotechnology, 26:1445-1454, DOI: 10.1007/ s11274-010-0319-5, 2010 .

7. Anonymous. Screentec inspection and systems, voedingsmiddelentechnologie,: 35, p6, 2002.

8. Anonymous. New E.coli research offers safer meat processing Available at: http://www.foodproductiondaily. com/news/newsng.asp?n=53813-new-e-coli.Accessed 21 February 2008, 2004.

9. FDA/USDA. Food and Drug Administration/ United States Department of Agriculture, 2003.

10. R. Thomas, A. S. R. Anjaneyulu and N. Kondaiah. Effect of hot-boned pork on the quality of hurdle treated pork sausages during ambient temperature $\left(37 \pm 1^{\circ} \mathrm{C}\right)$ storage. Food Chemistry, 107(2): 804-812, 2008.

11. A. Lianou and J. N. Sofos. A review of the incidence and transmission of Listeria monocytogenes in ready-to-eat products in retail and food service environments. J Food Prot., 70(9):2172-98, 2007.

12. M. Uyttendaele, P. De Troy and J. Debevere. Incidence of Salmonella, Campylobacter jejuni, Campylobacter coli and Listeria monocytogenes in poultry carcasses and different types of poultry products for sale on the Belgian retail market. J Food Prot, 62: 735-750, 1999.

13. C. L. Little and J. de Louvois. The microbiological examination of butchery products and butchers' premises in the United Kingdom. Journal of Applied Microbiology, 85(1), 177 - 186, 1998.

14. R. R. Beumer, M. C. te Giffel, E de Boer and F. M. Rombouts. Growth of Listeria monocytogenes on sliced cooked meat products. Food Microbiology, 13: 333-340, 1996.

15. M.L.A. Meat \& Livestock Australia. Through chain risk profile for the Australian red meat industry, PRMS.038c, part 1: risk profile. North Sydney: Meat and Livestock Australia, 2003.

16. G. Webster, L. Yarram, E. Freese, J. Koster, H. Sass, R. J. Parkes and A. J. Weightman Distribution of candidate division JS1 and other Bacteria in tidal sediments of the German Wadden Sea using targeted 16S rRNA gene PCR-DGGE. FEMS Microbiol Ecol, 62:78-89, 2007.

17. W. H. Andrews, S. Thomas and Hammack Chapter 5, Salmonella; Bacteriological Analytical Manual $8^{\text {th }}$ edition revision A, 1998.

18. American Public Health Association (APHA). Standard methods for the examination of water and waste water. American Health Associations, Washington DC, 1995.

19. N. M. Sachindra, P. Z. Sakhare and D. Narasimha Rao Reduction in microbial load on buffalo meat by hot water dip treatment. Meat Sci., 48(1/2): 149-157, 1998.

20. W. Tawakkol and N. I. Khafaga Fungal Contamination of Meat and its Environment with Special Reference to the Strains Producing Aflatoxins, Ochratoxins, Proteinase and Lipase Enzymes. New Egyptian Journal of Microbiology, 17 (2):1-14, 2007. 